\begin{tabular}{|l|l|l||}
\hline \multicolumn{2}{|c|}{ PublisherInfo } \\
\hline \hline PublisherName & $:$ & BioMed Central \\
\hline \hline PublisherLocation & $:$ & London \\
\hline \hline PublisherImprintName & $:$ & BioMed Central \\
\hline \hline
\end{tabular}

\title{
Phototrophs at sea
}

\begin{tabular}{|l|c|l||}
\hline \multicolumn{2}{|c|}{ ArticleInfo } \\
\hline \hline ArticleID & $:$ & 4396 \\
\hline \hline ArticleDOI & $:$ & $10.1186 /$ gb-spotlight-20020208-01 \\
\hline \hline ArticleCitationID & $:$ & spotlight-20020208-01 \\
\hline \hline ArticleSequenceNumber & $:$ & 62 \\
\hline \hline ArticleCategory & $:$ & Research news \\
\hline ArticleFirstPage & $:$ & 1 \\
\hline \hline ArticleLastPage & $:$ & 2 \\
\hline \hline & & RegistrationDate : 2002-2-8 \\
\hline ArticleHistory & $:$ & OnlineDate \\
\hline \hline ArticleCopyright & $:$ & BioMed Central Ltd2002-2-8 \\
\hline \hline ArticleGrants & $:$ & \\
\hline \hline ArticleContext & $:$ & 130593311 \\
\hline \hline
\end{tabular}




\section{Jonathan B Weitzman}

Email: jonathanweitzman@hotmail.com

Aerobic phototrophic bacteria need oxygen for growth and for synthesis of bacteriochlorophyll $a$. In the February 7 Nature Béjà et al. report analysis of the photosynthetic gene clusters and operon organization in uncultivated marine bacteria (Nature 2002, 415:630-633). They found evidence for considerable phototroph diversity and for unexpected proteobacterial subgroups. They performed reverse-transcriptase-coupled-PCR and genomic analysis of bacterial artificial chromosomes to identify photosynthetic genes in samples of mixed bacterioplankton from Monterey Bay in California and from the North Pacific Ocean. Their results demonstrate that plankton assemblages are made up of multiple, distantly related bacterial groups that participate in oceanic aerobic, bacteriochlorophyll-based photosynthesis. Such culture-independent genomic techniques will reveal the richness of uncharacterized marine ecosystems.

\section{References}

1. Aerobic anoxygenic phototrophic bacteria.

2. Nature, [http://www.nature.com] 